\title{
Reaction Behavior of the Li-N-H Hydrogen Storage System with Boron Nitride as an Additive
}

\begin{abstract}
LINNAN DU, GEORG MAUER, and ROBERT VABEN
This work begins with a discussion of the desorption, reaction rate-limiting step of a $\mathrm{LiNH}_{2}-\mathrm{LiH}$ hydrogen storage system. Using microstructural and thermodynamic studies, it explains the working mechanism of $\mathrm{BN}$ as an additive in Li-N-H hydrogen storage materials. High-energy wet ball milling with THF was applied to the $\mathrm{LiNH}_{2}+1.2 \mathrm{LiH}$ mixture. The results obtained in this work show that the rate-limiting step of the desorption reaction depends on the degree of oxidation and amount of $\mathrm{LiH}$ in the system. The activation energy of the desorption reaction of both ball-milled $\mathrm{LiNH}_{2}$ and $\mathrm{LiNH}_{2}+1.2 \mathrm{LiH}$ samples was reduced with $\mathrm{BN}$ as an additive. BN had no clear impact on the crystallite sizes of $\mathrm{LiNH}_{2}+1.2 \mathrm{LiH}$ as-milled samples. However, it was found that $\mathrm{BN}$ stabilizes the crystallite sizes of $\mathrm{LiNH}_{2}+1.2 \mathrm{LiH}$ samples during the hightemperature desorption and absorption processes.
\end{abstract}

DOI: $10.1007 / \mathrm{s} 40553-015-0043-\mathrm{z}$

(C) ASM International (ASM) and The Minerals, Metals \& Materials Society (TMS) 2015

\section{INTRODUCTION}

As a clean energy carrier, hydrogen has attracted great attention. It is carbon-free, abundantly available from water, and has an exceptional gravimetric energy density which can reach up to $142 \mathrm{MJ} / \mathrm{kg} .{ }^{[1]}$ However, the problem with hydrogen energy is that it exists as a low-density gas at atmospheric pressure and room temperature. Therefore, suitable solid-state hydrogen storage materials with high storage capacities are an important issue for the hydrogen energy economy.

The US Department of Energy (DOE) has defined standards for an on-board hydrogen storage system. The target for the year $2010^{[2,3]}$ was a system storage capacity exceeding $6 \mathrm{wt}$ pct $(2.0 \mathrm{kWh} / \mathrm{kg})$ at around $373 \mathrm{~K}\left(100{ }^{\circ} \mathrm{C}\right) \cdot{ }^{[4]}$ However, at the time of writing, a new target had been set ${ }^{[2]}$ for the year 2017, namely $5.5 \mathrm{wt}$ pct $(1.8 \mathrm{kWh} / \mathrm{kg})$. Due to the high theoretical storage capacity, many metal hydrides and complex hydrides have shown significant potential for use as reversible, solid, hydrogen storage materials. Of the complex hydride hydrogen storage materials, the $\mathrm{LiNH}_{2}+\mathrm{LiH}$ system has a relatively high theoretical storage capacity ( $>6 \mathrm{wt}$ pct) and a relatively low desorption temperature $\left[<523 \mathrm{~K}\left(250{ }^{\circ} \mathrm{C}\right)\right]$. In contrast to other metal hydrides or complex hydrides, the Li-N-H system is composed of both metallic and non-metallic elements in which the storage process involves the breaking and forming of non-metal hydrogen bonds. ${ }^{[5]}$ Chen et $a l^{[6]}$ were the first to describe the $\mathrm{Li}-\mathrm{N}-\mathrm{H}$ hydrogen storage system:

LINNAN DU, Scientific Assistant, GEORG MAUER, Head of Research Team, and ROBERT VAßEN, Head of Department, are with the Forschungszentrum Jülich GmbH, IEK-1, 52425 Jülich, Germany. Contact e-mail: g.mauer@fz-juelich.de

Manuscript submitted April 15, 2014.

Article published online February 11, 2015

$$
\mathrm{LiNH}_{2}+\mathrm{LiH} \leftrightarrow \mathrm{Li}_{2} \mathrm{NH}+\mathrm{H}_{2}
$$

Many studies have investigated the reaction mechanism of Reaction [1]..$^{[7,8]}$ First reported by $\mathrm{Hu}$ and Ruckenstein $^{[9]}$ and Ichikawa et al. ${ }^{[10]}$ it is now well accepted that the reaction shown in (1) can be further separated into two reaction steps: ${ }^{[11-15]}$

$$
\begin{gathered}
2 \mathrm{LiNH}_{2} \rightarrow \mathrm{Li}_{2} \mathrm{NH}+\mathrm{NH}_{3} \\
\mathrm{NH}_{3}+\mathrm{LiH} \rightarrow \mathrm{LiNH}_{2}+\mathrm{H}_{2}
\end{gathered}
$$

$\mathrm{LiNH}_{2}$ first decomposes into $\mathrm{Li}_{2} \mathrm{NH}$ and releases $\mathrm{NH}_{3}$; then $\mathrm{NH}_{3}$ reacts with $\mathrm{LiH}$ and $\mathrm{H}_{2}$ is released. The product $\mathrm{LiNH}_{2}$ decomposes and releases $\mathrm{NH}_{3}$ again, and this $\mathrm{NH}_{3}$ reacts with $\mathrm{LiH}$ further until all remaining $\mathrm{LiNH}_{2}$ and $\mathrm{LiH}$ transform into $\mathrm{Li}_{2} \mathrm{NH}$ and $\mathrm{H}_{2} \cdot{ }^{[7]}$

Despite its hydrogen capacity, the system is restricted by low reaction kinetics. ${ }^{[16]}$ As the thermodynamic properties of the $\mathrm{Li}-\mathrm{N}-\mathrm{H}$ system are thought to be poor, ${ }^{[17]}$ several scientists have tried to introduce $\mathrm{Mg}$ as an element or to use $\mathrm{MgH}_{2}$ instead of $\mathrm{LiH}$ together with $\mathrm{LiNH}_{2} \cdot{ }^{[18-22]}$ However, thermodynamically accurate results are still not available, because the kinetic properties are significantly worse. ${ }^{[23]}$ Besides lab work, some scientists also focused on identifying $\mathrm{LiNH}_{2}+$ $\mathrm{LiH}$ hydrogen storage system with first-principles calculation methods. ${ }^{[5,24,25]}$

Several papers ${ }^{[7,9,14,26]}$ report that the reaction rate of Reaction [3] is very fast. However, Yao suggested that the rate-limiting step should be Reaction [3]. ${ }^{[12]}$ Using $\mathrm{Mn}$ and $\mathrm{V}$ as additives, Yao and co-workers successfully enhanced the release of $\mathrm{NH}_{3}$ from $\mathrm{LiNH}_{2}$, but this had little influence on the production of $\mathrm{H}_{2}{ }^{[12]}$ Varin ${ }^{[13]}$ assumed that $\mathrm{LiH}$ partially reacts with residual oxygen and water vapor, forming $\mathrm{LiOH}$, and that it thus becomes inactive for Reaction [3], which is a major 
impediment to hydrogen desorption. They suggested using a little more $\mathrm{LiH}$ with a molecular ratio of $\mathrm{LiNH}_{2}$ to $\mathrm{LiH}$ of $1: 1.2$. With regard to another aspect, Pinkerton found that the reaction rate was dependent on the sample amount. Larger sample sizes are more likely to develop local $\mathrm{NH}_{3}$ concentrations which are high enough to inhibit further reaction. ${ }^{[27]} \mathrm{He}$ believed that the activation energy for the decomposition reaction was independent of the milling time. However, Shaw et al. came to a different conclusion. ${ }^{[28]}$ Obviously, there is still no consensus about the reaction mechanism and the rate-limiting step. For this reason, the present work will firstly focus on clarifying the desorption mechanisms. The desorption experiments with $\mathrm{LiNH}_{2}$ samples are performed in both gravimetric and volumetric systems at the same desorption temperature. The results are then compared and analyzed.

In order to improve the desorption properties, several additives have been used with the Li-N-H system, for example $\mathrm{Ti}$ (nanoparticles), $\mathrm{Ti}$ (microparticles), $\mathrm{TiO}_{2}$ (nanoparticles), $\mathrm{TiO}_{2}$ (microparticles), ${ }^{29]} \mathrm{TiCl}_{3},{ }^{[29-32]}$ $\mathrm{Mn}, \mathrm{V},{ }^{[12]}$ etc. Recently, Dong et al. showed that $\mathrm{KBr}$, $\mathrm{KCl}, \mathrm{KF}$, and $\mathrm{KOH}$ effectively enhance the reaction kinetics between $\mathrm{LiH}$ and $\mathrm{NH}_{3} \cdot{ }^{[33]}$ Compared with other additives, nitrides were then proposed as a new group of additives. BN was reported to improve the dehydrogenation rate of the $\mathrm{Li}-\mathrm{N}-\mathrm{H}$ system $^{[16]}$ and improve $\mathrm{Li}+$ diffusion between $\mathrm{LiNH}_{2}$ and $\mathrm{LiH}^{[8]}$ High-energy dry ball milling ${ }^{[10,12,28]}$ and hollow nanosphere structures ${ }^{[34]}$ have also been used to enhance the kinetics of reaction. In our previous work, we also found that 3 wt pet BN successfully improved the recyclability of the $\mathrm{LiNH}_{2}+\mathrm{LiH}$ system. ${ }^{[35]}$ However, the detailed mechanism is still unclear. Thus, this work also aims to detail the hydrogen storage ability of the $\mathrm{LiNH}_{2}+1.2 \mathrm{LiH}$ system with and without $\mathrm{BN}$ as an additive. The changes in desorption activation energies, enthalpies, and crystallite sizes were studied and compared during desorption of the $\mathrm{LiNH}_{2}+$ 1.2 LiH wet ball-milled samples with and without BN.

\section{EXPERIMENTAL METHODS}

Lithium amide $\left(\mathrm{LiNH}_{2}\right.$, purity $\left.95 \mathrm{pct}\right)$ and lithium hydride (LiH, purity 98 pct) were purchased as powders from Sigma-Aldrich Chemie GmbH. Tetrahydrofuran (THF, purity 99.5 pct) was supplied by Acros Organics. The additive (BN, purity 98 pct) was purchased from Sigma-Aldrich Chemie GmbH. All samples were stored and handled in a glove box under a protective argon atmosphere. The molecular ratio between $\mathrm{LiNH}_{2}$ and $\mathrm{LiH}$ was set to $1: 1.2$, as suggested in Reference 13. The planetary ball milling method was applied in this study using planetary mills PM 400 (RETSCH GMBH, Germany). Similar to References 35,36, the samples in the present work were wet ball milled with THF. Yttriastabilized zirconia (YSZ) milling balls (Tosoh Corporation, Japan) were used as milling media. The weight ratio between $\mathrm{THF}$ and the sample material was $4: 1$. This resulted in a mixture of $20 \mathrm{~g}$ THF and $50 \mathrm{~g}$ milling balls per $5 \mathrm{~g}$ sample powder. Samples in this study were milled with a mixture of milling balls with different diameters. The weight ratio between $5 \mathrm{~mm}$ milling balls and $2 \mathrm{~mm}$ milling balls was 7:3. The milling time was 72 hours. After milling, the wet ball-milled suspensions were stored in the glove box for about 20 hours in order to evaporate the THF.

Desorption measurements of the wet ball-milled $\mathrm{LiNH}_{2}$ samples were processed first in the volumetric apparatus BELSORP-HP (BEL Japan, Osaka, Japan) and in the gravimetric system IsoSORP-Hygra (RUBOTHERM GmbH, Bochum, Germany) at $573 \mathrm{~K}$ $\left(300{ }^{\circ} \mathrm{C}\right)$. As the BELSORP-HP system is a closed volume system, the pressure change during the sorption experiment can be measured and recorded. The weight changes of the samples during the sorption process are calculated based on the pressure change. The ISOSORPHygra comprises a magnetic suspension balance. During the experiment, the pressure can be kept at a specified value (in this work it was kept as vacuum), and the weight change of the sample can be read directly.

In order to study the $\mathrm{BN}$ influence on the desorption enthalpy of the $\mathrm{LiNH}_{2}+1.2 \mathrm{LiH}$ samples, hydrogen desorption measurements of the wet ball-milled samples with and without BN were processed in the volumetric apparatus BELSORP-HP. Samples were desorbed at 4 different temperatures in the range from $523 \mathrm{~K}$ to $598 \mathrm{~K}$ $\left(250{ }^{\circ} \mathrm{C}\right.$ to $\left.325^{\circ} \mathrm{C}\right)$. The desorption time was 3 hours in each case. Based on the different equilibrium pressures arising at the different temperatures in the Belsorp-HP system, the enthalpy change of the desorption was calculated using the Van't Hoff equation.

About $60-70 \mathrm{mg}$ of $\mathrm{LiNH}_{2}$ and $\mathrm{LiNH}_{2}+1.2 \mathrm{LiH}$ ball-milled samples with and without $\mathrm{BN}$ was also studied with DTA/TG methods (STA449C Jupiter, Netzsch). The samples were heated from $323 \mathrm{~K}$ to $673 \mathrm{~K}\left(50{ }^{\circ} \mathrm{C}\right.$ to $\left.400{ }^{\circ} \mathrm{C}\right)$ or $573 \mathrm{~K}\left(300{ }^{\circ} \mathrm{C}\right)$ at heating rates of 1,2 , and $5 \mathrm{~K} /$ minute with $\mathrm{Ar}$ as the desorption atmosphere, respectively. Based on the DTA profile, the activation energies of Reactions [1] and [2] were calculated by means of the Kissinger method. ${ }^{[37]}$

The phase compositions of the $\mathrm{LiNH}_{2}+1.2 \mathrm{LiH}$ asmilled samples and the samples after sorption were analyzed by X-ray diffraction (XRD) with a Bruker D4 ENDEAVOUR diffractometer (Bruker AXS GmbH, Karlsruhe). The wet ball-milled $\mathrm{LiNH}_{2}+1.2 \mathrm{LiH}$ samples with and without $\mathrm{BN}$ were desorbed at $523 \mathrm{~K}$ $\left(250{ }^{\circ} \mathrm{C}\right)$. After this, absorption experiments were performed with some of these samples. The absorption temperature was $473 \mathrm{~K}\left(200{ }^{\circ} \mathrm{C}\right)$ with an initial absorption pressure of approx. $1000 \mathrm{kPa}$. The desorption and absorption time for each sample was 3 hours, respectively. Based on the XRD information, the crystallite sizes of the samples were determined by applying the Williamson-Hall method. ${ }^{[38]}$

\section{RESULTS}

\section{A. Desorption Analysis of $\mathrm{LiNH}_{2}$ Samples}

\section{BN influence on the desorption of $\mathrm{LiNH}_{2}$}

Figure 1(a) illustrates the slow hydrogen desorption kinetics for both of the $\mathrm{LiNH}_{2}$ samples with and without 


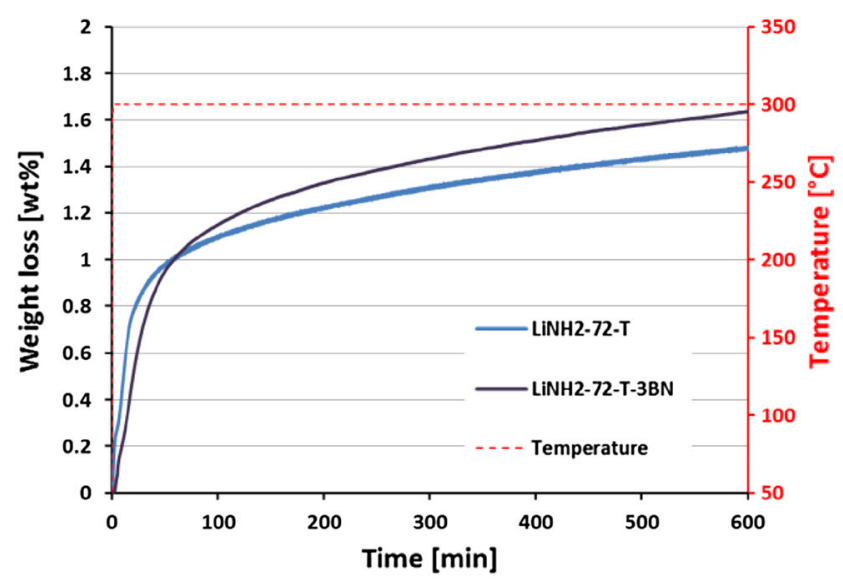

(a)

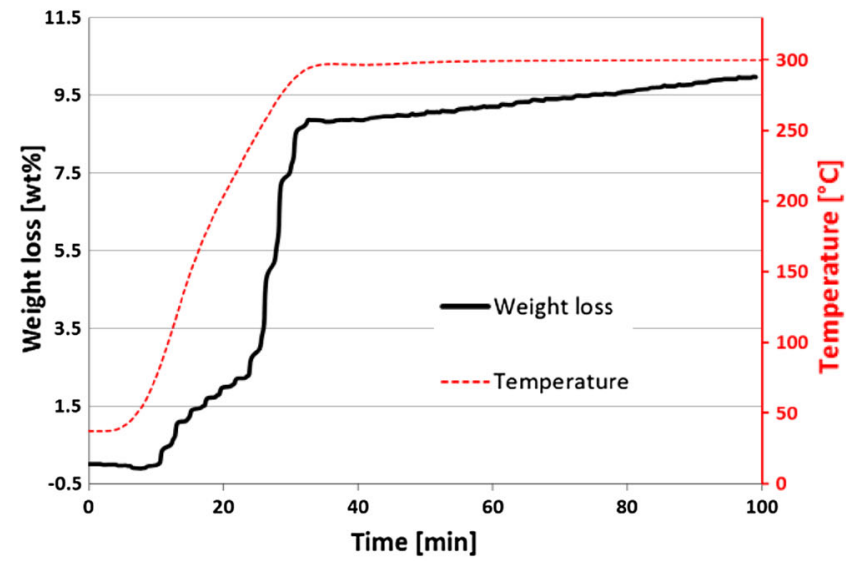

(b)

Fig. 1-(a) $\mathrm{LiNH}_{2}$ samples (with and without $\left.\mathrm{BN}\right)$ : desorption profile at $573 \mathrm{~K}\left(300{ }^{\circ} \mathrm{C}\right)$ in the volumetric Belsorp-HP system; $(b) \mathrm{LINH}_{2}$ sample with $\mathrm{BN}\left(\mathrm{LiNH}_{2}-72-\mathrm{T}\right)$ : desorption profile at $573 \mathrm{~K}\left(300^{\circ} \mathrm{C}\right)$ in the gravimetric magnetic suspension balance system; the dashed red lines indicate the temperature profile (Color figure online).

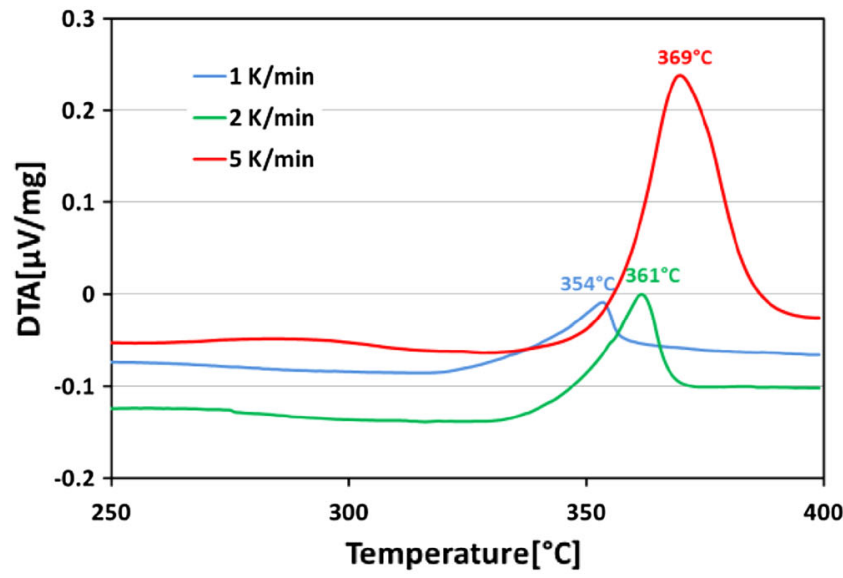

(a)

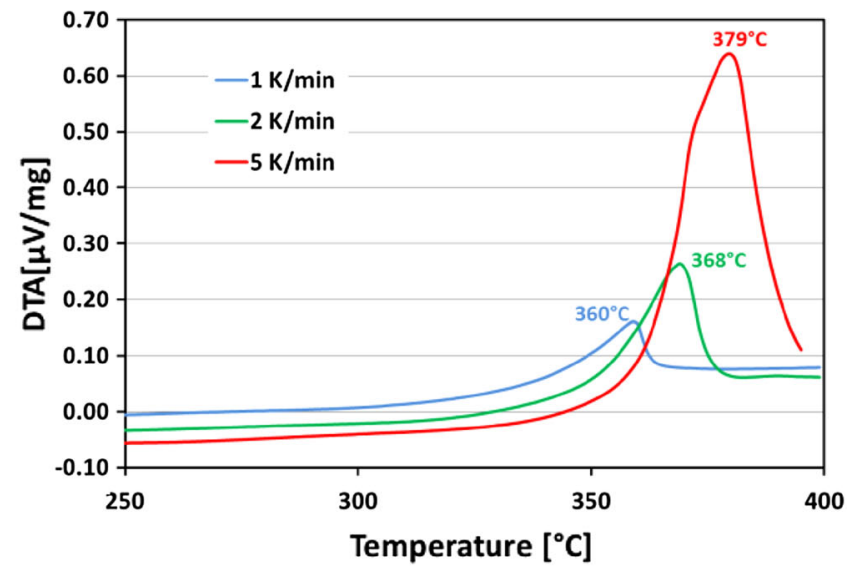

(b)

Fig. 2-DTA results of (a) $\mathrm{LiNH}_{2}: 72 \mathrm{~h}$ wet ball milled; (b) $\mathrm{LiNH}_{2}+3$ wt pct $\mathrm{BN}$ : $72 \mathrm{~h}$ wet ball milled; heating rate 1, 2, and $5 \mathrm{~K} / \mathrm{min}$, experiment atmosphere: Ar.

$\mathrm{BN}$, respectively, desorbed at $573 \mathrm{~K}\left(300{ }^{\circ} \mathrm{C}\right)$ with the volumetric Belsorp-HP system. The maximum weight loss of $\mathrm{LiNH}_{2}$ is theoretically 36.9 pct. With this volumetric system, only around 1.4-1.7 wt pct weight loss was achieved within 550 minute. Figure 1(b) shows the desorption profile of a $61 \mathrm{mg} \mathrm{LiNH}_{2}$ sample (without $\mathrm{BN})$ at $573 \mathrm{~K}\left(300{ }^{\circ} \mathrm{C}\right)$ with the gravimetric (IsoSORP-MSB) system. During the heating process, the pressure of the system was kept at vacuum level. It is obvious that the weight loss measured with the IsoSORP-MSB system had already reached $10 \mathrm{pct}$ within $100 \mathrm{~min}$. After a temperature of $573 \mathrm{~K}\left(300{ }^{\circ} \mathrm{C}\right)$ was reached, the weight loss rate tended to be constant. The desorption rate was much higher than the result obtained with the Belsorp-HP system.

2. BN influence on the desorption activation energy of $\mathrm{LiNH}_{2}$ samples

DTA analyses were performed with $\mathrm{LiNH}_{2}$ samples. All DTA experiments with the $\mathrm{LiNH}_{2}$ samples revealed one prominent endothermic peak in the temperature range between $623 \mathrm{~K}$ and $673 \mathrm{~K}\left(350{ }^{\circ} \mathrm{C}\right.$ and $\left.400{ }^{\circ} \mathrm{C}\right)$ (see Figure 2), which is in agreement with the published data from Varin and Yang. ${ }^{[1]}$ Based on the peak temperatures and heating rates, the activation energies of the samples were calculated using the Kissinger method. The corresponding linear fits are shown in Figure 3. The resulting activation energies were $321.8 \pm 33.2 \mathrm{~kJ} / \mathrm{mol} \mathrm{NH}_{3}$ and $260.2 \pm 18.0 \mathrm{~kJ} / \mathrm{mol}$ $\mathrm{NH}_{3}$, respectively. Both $R^{2}$ values (the square of the linear regression coefficient) were better than 0.95 . The results suggest that the addition of $\mathrm{BN}$ can lower the activation energy of the $\mathrm{LiNH}_{2}$ decomposition reaction.

\section{B. Study of $\mathrm{LiNH}_{2}+1.2 \mathrm{LiH}$ Samples}

\section{BN influence on the desorption enthalpy of} $\mathrm{LiNH}_{2}+1.2 \mathrm{LiH}$ samples

In order to study the $\mathrm{BN}$ influence on the desorption enthalpy of the samples, the desorption results are 
illustrated in Figure 4. The higher the desorption temperature, the faster the initial desorption kinetics and the higher the final pressure, which was reached after approx. 60 minute.

Applying the Van't Hoff equation, the enthalpy can be derived from a plot of $\ln \left(P / P_{0}\right)$ vs $1000 / T$. For each sample, there were 4 data points at 4 different temperatures. Figure 5 illustrates the linear fits. From the slopes of the regression lines, the desorption enthalpies and entropies were calculated and are given in the figures. The $R^{2}$ values were larger than 0.93 .

Considering the margin of error, there are no significant differences between samples with and without $\mathrm{BN}(33 \pm 4$ and $30 \pm 4 \mathrm{~kJ} / \mathrm{mol})$. The results clearly illustrate that $\mathrm{BN}$ has no influence as an additive on the desorption enthalpy.

Chen et al. ${ }^{[6]}$ reported a desorption enthalpy of $45 \mathrm{~kJ} / \mathrm{mol}$. Varin and Yang ${ }^{[11]}$ published an enthalpy of $62.4 \mathrm{~kJ} / \mathrm{mol}$ for the material system without an

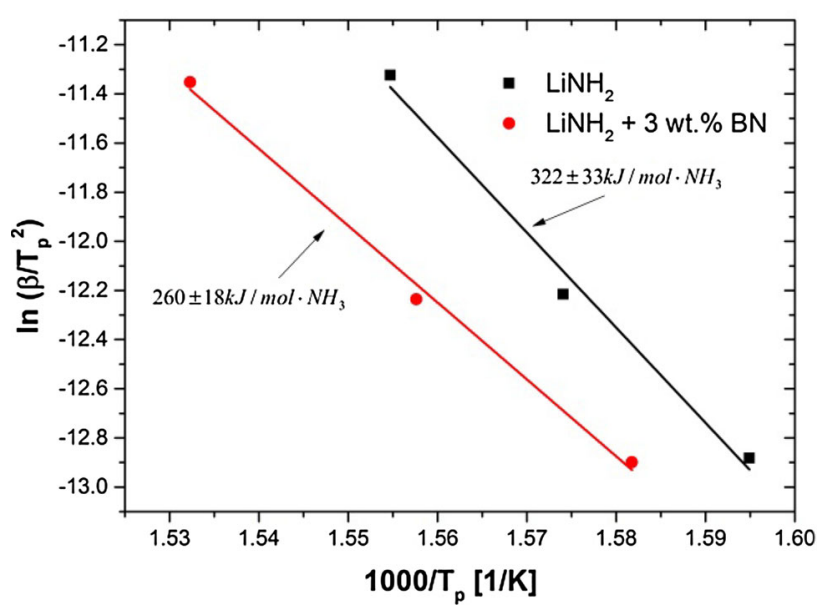

Fig. 3-Based on the DTA data in Fig. 2, the activation energy was calculated for $\mathrm{LiNH}_{2}$ samples with and without BN using the Kissinger method.

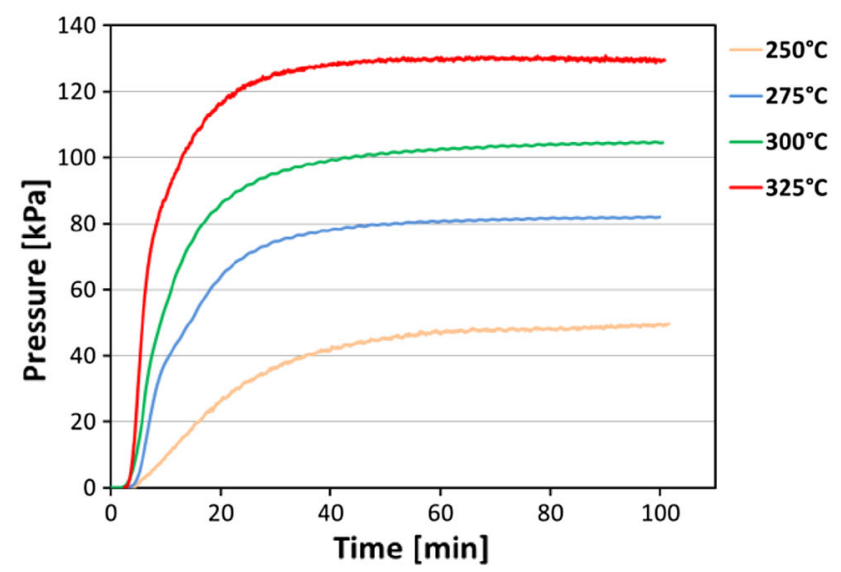

(a) additive. Although slightly lower, the results of this study are in reasonable accordance with their work.

2. BN influence on the desorption activation energy of $\mathrm{LiNH}_{2}+1.2 \mathrm{LiH}$ samples

Similar to $\mathrm{LiNH}_{2}$ single-component samples, the $\mathrm{LiNH}_{2}+1.2 \mathrm{LiH}$ samples were studied using the DTA method. The results are shown in Figure 6.

Similar to the findings of Yao et al..$^{[12]}$ and Varin et al. ${ }^{[13]}$ the weight losses of the samples were accompanied by a very broad endothermic DTA peak. In order to calculate the activation energy, the peak point $\left(T_{\mathrm{p}}\right)$ of the DTA result was determined. For each sample material, the 3 heating rates yielded 3 DTA peaks. A linear regression of $\ln \left(\beta / T_{\mathrm{p}}^{2}\right.$ ) ( $\beta$ being the heating rate) as a function of $1000 / T_{\mathrm{p}}$ yielded the lines in Figure 7 . The corresponding $R$-square values were larger than 0.95 . Applying the Kissinger method, the activation energy $E_{\mathrm{a}}$ can be calculated from the slope of the linear fit curves in Figure 7. For the sample without additives, $E_{\mathrm{a}}$ was calculated as $84.7 \pm 12.0 \mathrm{~kJ} / \mathrm{mol}$, which is very close to the published data $(85 \mathrm{~kJ} / \mathrm{mol})$ for the same system. ${ }^{[11]}$ For the sample with $3 \mathrm{wt}$ pct $\mathrm{BN}$, a significantly lower activation energy $E_{\mathrm{a}}$ of $68.0 \pm 6.5 \mathrm{~kJ} / \mathrm{mol}$ was calculated.

3. BN influence on the crystallite sizes of $\mathrm{LiNH}_{2}+$ 1.2LiH samples after desorption/absorption cycles

The XRD patterns of the samples as-milled and after desorption and absorption are shown in Figure 8. From the results, it can be seen that for the as-milled samples and the samples after absorption, the main phases are $\mathrm{LiNH}_{2}$ and $\mathrm{LiH}$. For the samples after desorption, the main phase is $\mathrm{Li}_{2} \mathrm{NH}$. Obviously, the existence of $\mathrm{BN}$ does not significantly affect the phase change of the sample during milling and sorption processes.

Based on the XRD pattern data, the crystallite sizes of the milled samples and the samples after desorption/ absorption were calculated by applying the WilliamsonHall method. The calculation results are shown in Figure 9.

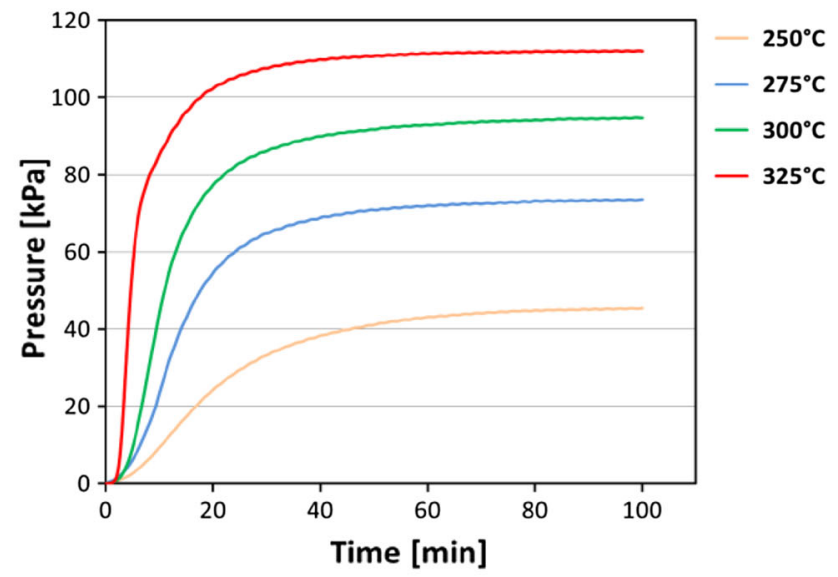

(b)

Fig. 4 -Desorption profiles of samples in the volumetric Belsorp-HP system. (a) $\mathrm{LiNH}_{2}+1.2 \mathrm{LiH}$; (b) $\mathrm{LiNH}_{2}+1.2 \mathrm{LiH}+3$ wt pct $\mathrm{BN}$; desorption temperatures were $523 \mathrm{~K}, 548 \mathrm{~K}, 573 \mathrm{~K}$, and $598 \mathrm{~K}\left(250{ }^{\circ} \mathrm{C}, 275^{\circ} \mathrm{C}, 300{ }^{\circ} \mathrm{C}\right.$, and $\left.325^{\circ} \mathrm{C}\right)$. 


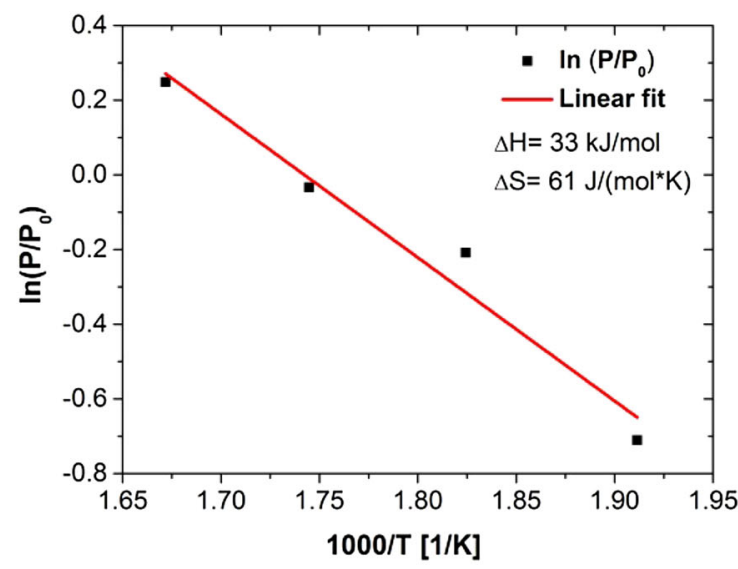

(a)

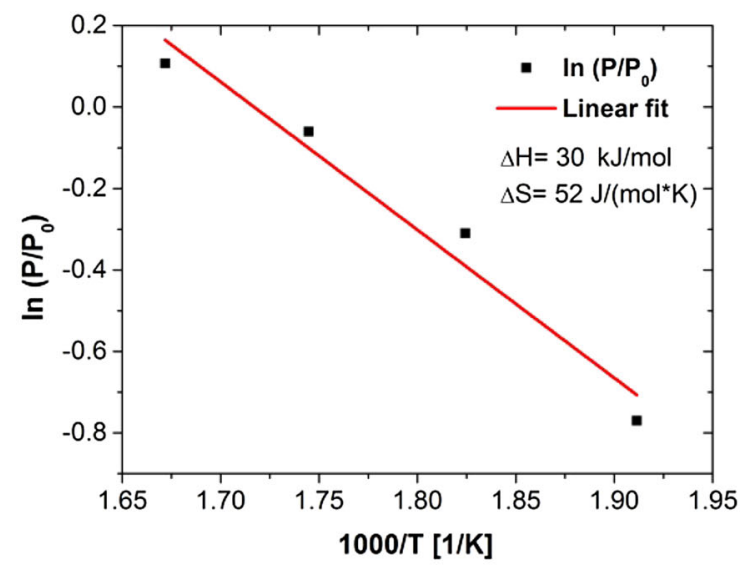

(b)

Fig. 5-Based on the result in Fig. 4, the enthalpy was calculated for the samples $(a) \mathrm{LiNH}_{2}+1.2 \mathrm{LiH}$ and $(b) \mathrm{LiNH}_{2}+1.2 \mathrm{LiH}+3$ wt pct $\mathrm{BN}$ using the Van't Hoff equation.

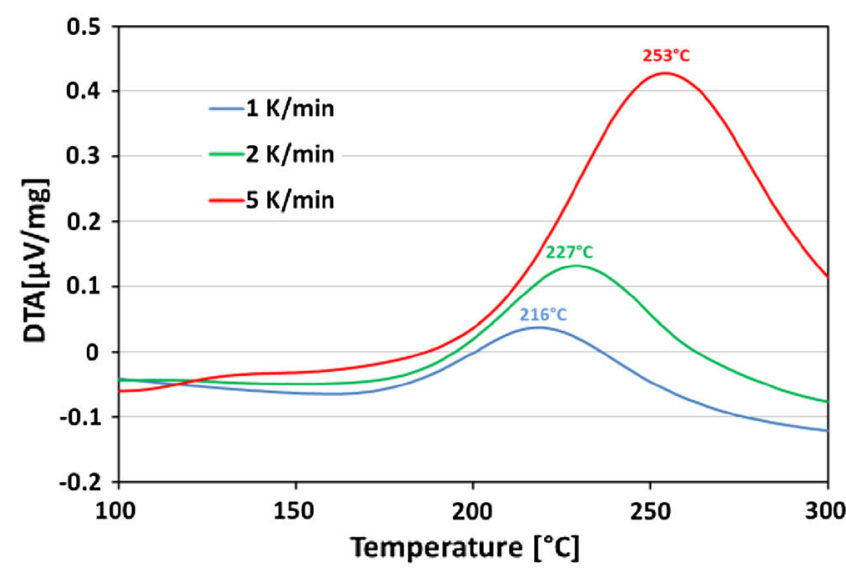

(a)

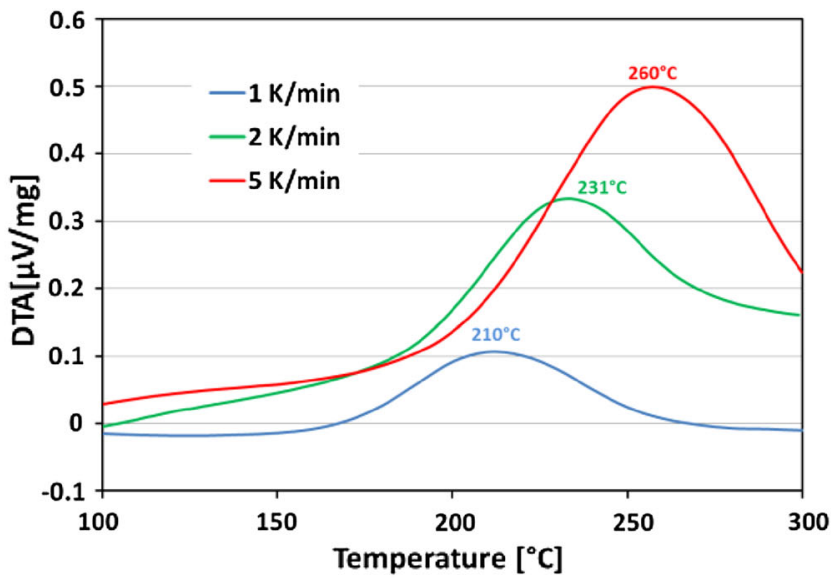

(b)

Fig. 6 -DTA results of $(a) \mathrm{LiNH}_{2}+1.2 \mathrm{LiH}$ and $(b) \mathrm{LiNH}_{2}+1.2 \mathrm{LiH}+3$ wt pct $\mathrm{BN}$ samples; heating rates: 1 , 2, and $5 \mathrm{~K} / \mathrm{min}$, experiment atmosphere: Ar.

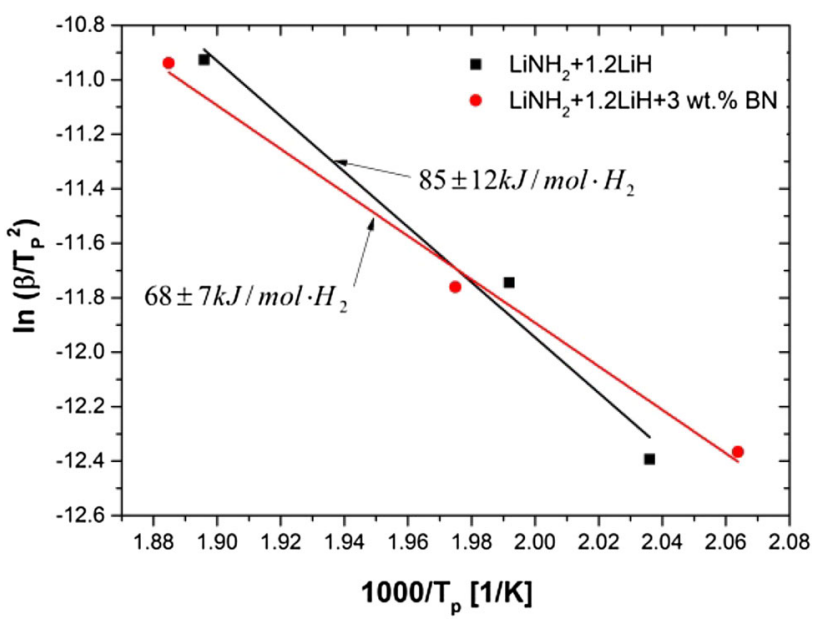

Fig. 7-Based on the result in Fig. 6, the activation energy was calculated for sample $\mathrm{LiNH}_{2}+1.2 \mathrm{LiH}$ with and without $\mathrm{BN}$ using the Kissinger method.
As shown in Figure 9, the crystallite size of the sample without BN increased after the 3-hour desorption. After the subsequent absorption, the crystallite size reached almost twice the size of the as-milled original. In contrast, after the same cycle of 3 hours of desorption and absorption, the sample with 3 wt pct $\mathrm{BN}$ showed no significant change in crystallite size, as can be seen in Figure 9. This might be an indication that $\mathrm{BN}$ efficiently stabilizes the crystallite size of the $\mathrm{LiNH}_{2}+1.2 \mathrm{LiH}$ system during hydrogen sorption processes.

\section{DISCUSSION}

\section{A. Reaction Process Analysis of Pure $\mathrm{LiNH}_{2}$}

In the former work, we found that $\mathrm{BN}$ as an additive clearly improves the recyclability of the $\mathrm{LiNH}_{2}+1.2$ LiH hydrogen storage materials. ${ }^{[35]}$ The present result in Figure 1(a) shows that the presence of $3 \mathrm{wt}$ pct BN had 


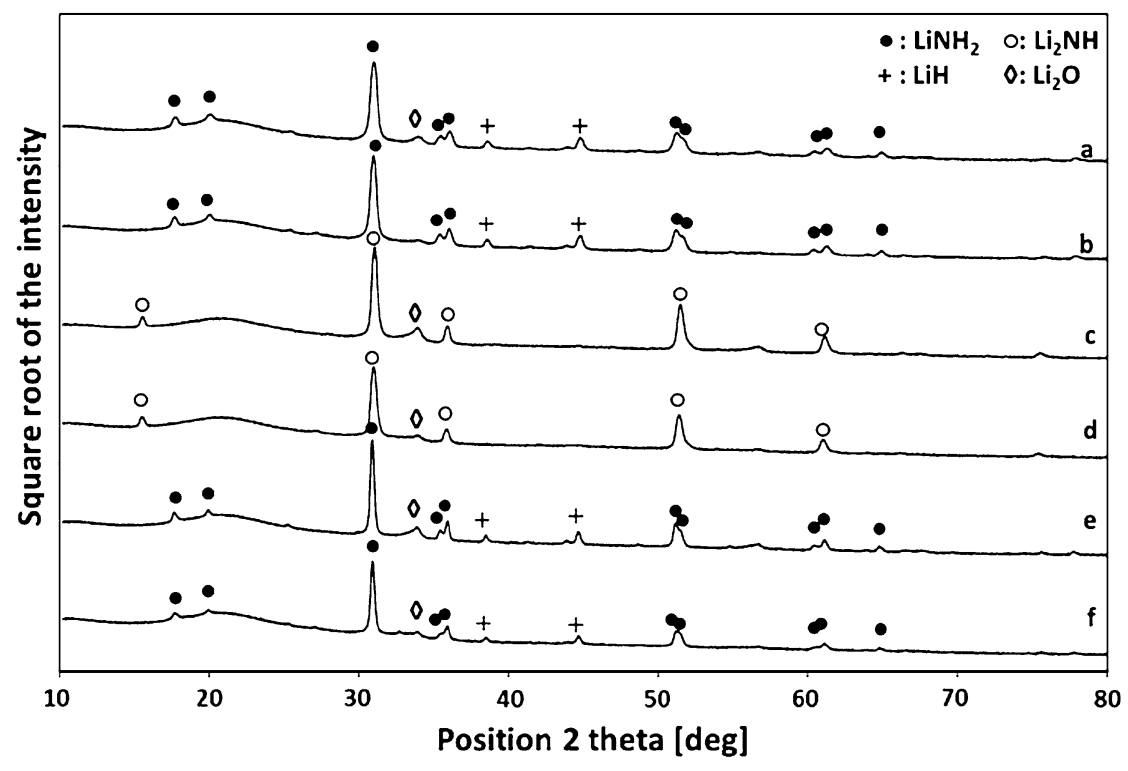

Fig. 8-XRD patterns of the samples $(a) \mathrm{LiNH}_{2}+1.2 \mathrm{LiH}, 72 \mathrm{~h}$ wet ball milled; $(b) \mathrm{LiNH}_{2}+1.2 \mathrm{LiH}+3$ wt pct $\mathrm{BN}, 72 \mathrm{~h}$ wet ball milled; $(c)$ $\mathrm{LiNH}_{2}+1.2 \mathrm{LiH}, 72 \mathrm{~h}$ wet ball milled, $523 \mathrm{~K}\left(250{ }^{\circ} \mathrm{C}\right) 3 \mathrm{~h}$ desorbed; $(d) \mathrm{LiNH}_{2}+1.2 \mathrm{LiH}+3 \mathrm{wt}$ pct $\mathrm{BN}, 72 \mathrm{~h}$ wet ball milled, $523 \mathrm{~K}\left(250{ }^{\circ} \mathrm{C}\right)$ 3 hours desorbed; $(e) \mathrm{LiNH}_{2}+1.2 \mathrm{LiH}, 72 \mathrm{~h}$ wet ball milled, $523 \mathrm{~K}\left(250{ }^{\circ} \mathrm{C}\right)$ desorbed, $473 \mathrm{~K}\left(200{ }^{\circ} \mathrm{C}\right)$ absorbed; $\mathrm{LiNH}_{2}+1.2 \mathrm{LiH}+3 \mathrm{wt}$ pct $\mathrm{BN}, 72 \mathrm{~h}$ wet ball milled, $523 \mathrm{~K}\left(250^{\circ} \mathrm{C}\right)$ desorbed, $473 \mathrm{~K}\left(200^{\circ} \mathrm{C}\right)$ absorbed.

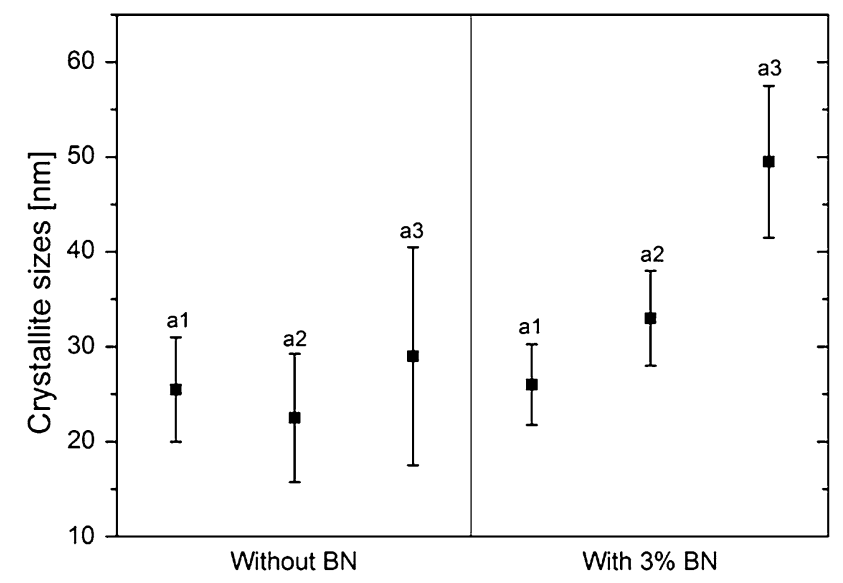

Fig. 9-Calculated $\mathrm{LiNH}_{2}+1.2 \mathrm{LiH}$ crystallite sizes of the two samples (with and without $\mathrm{BN})$ after milling (a1), $523 \mathrm{~K}\left(250^{\circ} \mathrm{C}\right), 3 \mathrm{~h}$ desorption (a2), and $473 \mathrm{~K}\left(200^{\circ} \mathrm{C}\right), 3 \mathrm{~h}$ absorption (a3), respectively.

no influence on the desorption kinetics of the $\mathrm{LiNH}_{2}$ sample, which is assumed to be the first step of the desorption process. This conclusion differs from the work of Nayebossadri et al. ${ }^{[16]}$ which assumed that $\mathrm{BN}$ can effectively improve the desorption rate of the sample. On the other hand, the results in this study show that the desorbed $\mathrm{NH}_{3}$ amount of $\mathrm{LiNH}_{2}$ at a desorption temperature of $573 \mathrm{~K} \quad\left(300{ }^{\circ} \mathrm{C}\right)$ differed considerably for the same period of time in the two analysis systems. The main difference between the two experimental conditions is the pressure. The higher $\mathrm{NH}_{3}$ pressure suppresses the further desorption process of $\mathrm{LiNH}_{2}$ very efficiently according to Eq. [2]. The low pressure in the IsoSORP-MSB system, however, supports the forward reaction of the gaseous desorption. In the vacuum condition, after the temperature reached
$573 \mathrm{~K}\left(300{ }^{\circ} \mathrm{C}\right)$, the desorption rate was constant. Every mol of the $\mathrm{LiNH}_{2}$ sample under study desorbed $1.70 \times 10^{-4} \mathrm{~mol} / \mathrm{minute} \mathrm{NH}_{3}$ at $573 \mathrm{~K}\left(300^{\circ} \mathrm{C}\right)$. This result verifies that if every $1 \mathrm{~mol}$ of $\mathrm{LiH}$ could react with $\mathrm{NH}_{3}$ at a rate higher than $1.70 \times 10^{-4} \mathrm{~mol} \mathrm{NH}_{3} /$ minute during the desorption process of the $\mathrm{LiNH}_{2}-\mathrm{LiH}$ system, the desorption of $\mathrm{LiNH}_{2}$ (which is Reaction [2]) would be the rate-limiting step. However, if every $1 \mathrm{~mol}$ of $\mathrm{LiH}$ could react with $\mathrm{NH}_{3}$ at a rate lower than $1.70 \times 10^{-4} \mathrm{~mol} \mathrm{NH}_{3} /$ minute, $\mathrm{NH}_{3}$ partial pressure would accumulate in the closed system. The result in Figure 1(a) shows that a low accumulated $\mathrm{NH}_{3}$ partial pressure during the desorption process can stop the desorption reaction of $\mathrm{LiNH}_{2}$. In this case, Eq. [3] is therefore the rate-limiting step.

\section{B. BN Influence on the $\mathrm{LiNH}_{2}+1.2 \mathrm{LiH}$ System}

As stated in Reference 35, the existence of $\mathrm{BN}$ can clearly improve the recyclability of the $\mathrm{LiNH}_{2}+1.2 \mathrm{LiH}$ samples. However, since the particle sizes of the doped and undoped $\mathrm{LiNH}_{2}+1.2 \mathrm{LiH}$ samples did not change during the desorption and absorption processes, the existence of BN obviously had no influence on the particle size. The results of the present study show furthermore that $\mathrm{BN}$ did not influence the desorption enthalpy of the $\mathrm{LiNH}_{2}+1.2 \mathrm{LiH}$ system either. However, the desorption activation energies of both $\mathrm{LiNH}_{2}$ and $\mathrm{LiNH}_{2}+1.2 \mathrm{LiH}$ samples were reduced effectively by $\mathrm{BN}$ doping. This suggests that $\mathrm{BN}$ reduced the activation energy of the $\mathrm{LiNH}_{2}$ desorption process, which is also the first step of the $\mathrm{LiNH}_{2}+1.2 \mathrm{LiH}$ desorption process, and then reduced the activation energy of the $\mathrm{LiNH}_{2}+1.2 \mathrm{LiH}$ desorption process. One possible reason for this may be that $\mathrm{BN}$ as a very stable phase inhibited the possible grain boundary growth during the high-energy milling process. 
This effect aided material diffusion during the sorption reaction and reduced the activation energy barrier of the desorption reaction. The desorption enthalpy remained unaffected, as expected. During the desorption process, $\mathrm{BN}$ acted as an additive that reduced the activation energy but did not change the reaction mechanism of the sorption reaction.

The results of the XRD analyses show that $\mathrm{BN}$ did not alter the crystallite sizes of the $\mathrm{LiNH}_{2}$ or $\mathrm{LiNH}_{2}+1.2 \mathrm{LiH}$ as-milled samples. However, BN efficiently stabilized the crystallite sizes during the sorption process. BN is a very stable phase during the sorption process. One possible reason why it stabilizes the crystallite sizes may be that the BN particles distributed throughout the samples efficiently inhibited the crystallite growth of the $\mathrm{LiNH}_{2}+1.2 \mathrm{LiH}$ samples during the sorption process. This result indicates that the decreasing kinetics of the sample without $\mathrm{BN}$ during the desorption cycling were due to the increase in the sample's crystallite size. By doping with $\mathrm{BN}$, the crystallite size was kept small and thus a larger number of grain boundaries were achieved. This result combined with the fact that $\mathrm{BN}$ improved the recyclability of $\mathrm{LiNH}_{2}+\mathrm{LiH}$ samples allows us to conclude that the smaller crystallite sizes and larger grain boundaries aided the sorption processes of $\mathrm{LiNH}_{2}+1.2 \mathrm{LiH}$ hydrogen storage samples.

\section{CONCLUSIONS}

1. Thermodynamically, $\mathrm{LiH}$ is very reactive and the reaction between $\mathrm{LiH}$ and $\mathrm{NH}_{3}$ is very fast. However, practically $\mathrm{LiH}$ is reactive and can react with residual oxygen and water vapor to form $\mathrm{LiOH}$ or $\mathrm{Li}_{2} \mathrm{O}$. This makes $\mathrm{LiH}$ inactive for Reaction [3], which impedes the hydrogen desorption of the $\mathrm{LiNH}_{2}-\mathrm{LiH}$ system. In the study with the gravimetric system, it was shown that every $1 \mathrm{~mol}$ of the $\mathrm{LiNH}_{2}$ sample desorbed $1.70 \times 10^{-4} \mathrm{~mol} /$ minute $\mathrm{NH}_{3}$ at $573 \mathrm{~K}\left(300{ }^{\circ} \mathrm{C}\right)$. This means that during the desorption process of the $\mathrm{Li}-\mathrm{N}-\mathrm{H}$ system, if every $1 \mathrm{~mol}$ of $\mathrm{LiH}$ (or $1.2 \mathrm{~mol} \mathrm{LiH}$ in the $\mathrm{LiNH}_{2}+1.2$ LiH system) could react with $\mathrm{NH}_{3}$ at a rate higher than $1.70 \times 10^{-4}$ mol $\mathrm{NH}_{3} /$ minute, the desorption of $\mathrm{LiNH}_{2}$ (which is Reaction [2]) would be the ratelimiting step. Otherwise, $\mathrm{NH}_{3}$ partial pressure will accumulate in the closed system and Reaction [3] will become the rate-limiting step.

2. $\mathrm{BN}$ as an additive efficiently decreases the desorption activation energies of the $\mathrm{LiNH}_{2}$ and $\mathrm{LiNH}_{2}+$ 1.2 LiH samples. However, $\mathrm{BN}$ does not influence the desorption enthalpy of the $\mathrm{LiNH}_{2}+1.2 \mathrm{LiH}$ samples. One possible reason for this may be that the existence of $\mathrm{BN}$ inhibits the crystal growth during the high-energy milling process, aiding material diffusion during the sorption reaction. However, $\mathrm{BN}$ has no influence on the desorption reaction mechanism or on the reaction enthalpy.

3. BN has no clear influence on the crystallite sizes of either the $\mathrm{LiNH}_{2}$ or $\mathrm{LiNH}_{2}+1.2 \mathrm{LiH}$ as-milled samples. However, BN efficiently stabilizes the crys- tallite sizes during the sorption process. One possible reason may be that the distribution of $\mathrm{BN}$ throughout the $\mathrm{LiNH}_{2}+1.2 \mathrm{LiH}$ samples prevents the crystallite growth of $\mathrm{LiNH}_{2}+\mathrm{LiH}$ during hightemperature desorption. This result suggests that smaller crystallite sizes and larger grain boundaries aided the sorption processes of $\mathrm{LiNH}_{2}+1.2 \mathrm{LiH}$ samples.

\section{REFERENCES}

1. D.P. Broom: Hydrogen Storage Materials, The Characterization of Their Storage Properties, Springer, London, 2010, p. 5.

2. United States Department of Energy, Office of Energy Efficiency and Renewable Energy and the Freedom CAR and Fuel Partnership: "Targets for Onboard Hydrogen Storage Systems for Light-Duty Vehicles", Washington, 2009.

3. L.E. Klebanoff and J.O. Keller: Int. J. Hydrogen Energy, 2013, vol. 38, pp. 4533-76.

4. W. Osborn, T. Markmaitree, L.D. Shaw, J.-Z. Hu, J. Kwak, and Z. Yang: Int. J. Hydrogen Energy, 2009, vol. 34, pp. 4331-39.

5. G. Miceli: Dissertation, Università degli Studi di Milano-Bicocca, 2010.

6. P. Chen, Z. Xiong, J. Luo, J. Lin, and L. Tan: Nature, 2002, vol. 420, pp. 302-304.

7. T. Ichikawa, N. Hanada, S. Isobe, H. Leng, and H. Fujii: J. Phys. Chem. B, 2004, vol. 108, pp. 7887-92.

8. K.F. Aguey-Zinsou, J. Yao, and Z.X. Guo: J. Phys. Chem. B, 2007, vol. 111, pp. 12531-36.

9. Y.H. Hu and E. Ruckenstein: J. Phys. Chem. A, 2003, vol. 107, p. 9739.

10. T. Ichikawa, S. Isobe, N. Hanada, and H. Fujii: J. Alloy Compd., 2004, vol. 365, pp. 271-76.

11. R.A. Varin and M. Jang: J. Alloy Compd., 2001, vol. 509, pp. 7143-51.

12. J.H. Yao, C. Shang, K.F. Aguey-Zinsou, and Z.X. Guo: J. Alloy Compd., 2007, vol. 432, pp. 277-82.

13. R.A. Varin, M. Jang, and M. Polanski: J. Alloy Compd., 2010, vol. 491, pp. 658-67.

14. T. Markmaitree, R. Ren, and L. Shaw: J. Phys. Chem. B, 2006, vol. 110, pp. 20710-18.

15. J. Lu, Z. Fang, Y.J. Choi, and H.Y. Sohn: J. Phys. Chem. C, 2007, vol. 111, pp. 12129-34.

16. S. Nayebossadri, K.F. Aguey-Zinsou, and Z.X. Guo: Int. J. Hydrogen Energy, 2011, vol. 36, pp. 7920-26.

17. M. Hirscher, ed., Handbook of Hydrogen Storage, Wiley-VCH, Weinheim, 2010, p. 161.

18. T. Ikeda, Y. Mikami, and T. Haruki: J. Phys. Chem. C, 2007, vol. 111, pp. 8389-96.

19. W. Luo: J. Alloy Compd., 2004, vol. 381, pp. 284-87.

20. Y. Nakamori, G. Kitahara, K. Miwa, N. Ohba, T. Noritake, S. Towata, and S. Orimo: J. Alloy Compd., 2005, vols. 404 406, pp. 396-98.

21. Z. Xiong, J. Hu, G. Wu, P. Chen, W. Luo, K. Gross, and J. Wang: J. Alloy Compd., 2005, vol. 398, pp. 235-39.

22. H. Leng, T. Ichikawa, S. Hino, N. Hanada, S. Isobe, and H. Fujii: J. Phys. Chem. B, 2004, vol. 108, pp. 8763-65.

23. M. Hirscher, ed.: Handbook of Hydrogen Storage, Wiley-VCH, Weinheim, 2010, pp. 162.

24. K. Miwa, N. Ohba, and S. Towata: Phys. Rev. B, 2005, vol. 71, p. 195109.

25. S.V. Alapati, J.K. Johnson, and D.S. Shol: J. Phys. Chem. B, 2006, vol. 110, pp. 8769-76.

26. L.L. Shaw, W. Osborn, T. Markmaitree, and X. Wan: J. Power Sources, 2008, vol. 177, pp. 500-505.

27. F.E. Pinkertion: J. Alloy Compd., 2005, vol. 400, pp. 76-82.

28. L.L. Shaw, R. Ren, T. Markmaitree, and W. Osborn: J. Alloy Compd., 2008, vol. 448, pp. 263-71. 
29. S. Isobe, T. Ichikawa, N. Hanada, H.Y. Leng, M. Fichtner, O. Fuhr, and H. Fujii: J. Alloy Compd., 2005, vols. 404-406, pp. 439-42.

30. T. Ichikawa, N. Hanada, S. Isobe, H. Leng, and H. Fujii: Mater. Trans., 2005, vol. 46, pp. 1-14.

31. S. Hino, T. Ichikawa, K. Tokoyoda, Y. Kojima, and H. Fujii: $J$. Alloy Compd., 2007, vols. 446-447, pp. 342-44.

32. T. Ichikawa, N. Hanada, S. Isobe, H.Y. Leng, and H. Fujii: $J$. Alloy Compd., 2005, vols. 404-406, pp. 435-38.

33. B. Dong, L. Song, Y. Teng, J. Ge, and S. Zhang: Int. J. Hydrogen Energy, 2014, vol. xxx, pp. 1-6.
34. L. Xie, J. Zheng, Y. Liu, Y. Li, and X. Li: Chem. Mater., 2008, vol. 20 , pp. 282-86.

35. L. Du, G. Mauer, and R. Vaßen: Energy Procedia, 2012, vol. 29, pp. 147-55.

36. L. Meng: Improved Hydrogen Sorption Kinetics in Wet Ball Milled Mg Hydrides, 1st ed., Forschungszentrum Juelich GmbH, Juelich, 2011, p. 38.

37. H.E. Kissinger: Anal. Chem., 1957, vol. 29, pp. 1702-06.

38. G.K. Williamson and W.H. Hall: Acta Metall., 1953, vol. 1, pp. 22-31. 